\title{
Dizygotic twins concordant for truncus arteriosus
}

\author{
Michael J. Lang', David J. Aughton', Thomas W. Riggs', Magdy P. Milad \\ AND LESLIE G. BIESECKER ${ }^{3}$ \\ 'Department of Pediatrics and ${ }^{2}$ Department of Obstetrics and Gynecology, William Beaumont \\ Hospital, Royal Oak, Michigan and ${ }^{3}$ Department of Pediatrics and Communicable Diseases, \\ University of Michigan School of Medicine, Ann Arbor, Michigan, USA
}

\begin{abstract}
Persistent truncus arteriosus (TA) is an uncommon congenital cardiovascular malformation, which comprises between $0.4 \%$ and $4 \%$ of all congenital heart defects. Occurrence of TA in siblings has been reported infrequently. Twins concordant for isolated TA appear to have been reported only once previously. In this paper, we describe dizygotic twin females who were concordant for isolated TA.
\end{abstract}

Received 29 May, revised 21 August, accepted for publication 23 August 1990

Key words: heart defects, congenital; hydrops fetalis; prenatal diagnosis; truncus arteriosus,

Persistent truncus arteriosus (TA) is an uncommon congenital cardiovascular malformation, which comprises between $0.4 \%$ (Kidd 1978) and 4\% (Mair et al. 1983) of all congenital heart defects. Occurrence of TA in siblings has been reported infrequently (Goodyear 1961, Brunson et al. 1978, Miller \& Smith 1979, Shapiro et al. 1981). Twins concordant for TA have been reported only three times previously. In two cases (Giustra \& Tosti 1939, Raghavan et al. 1983), TA was associated with more complex cardiac malformations or with multiple congenital anomalies. Concordance for isolated TA appears to have been described only once previously (Benešová \& Sikl 1954), in a monochorionic, "homologous" twin pair. In this paper, we describe dizygotic twins concordant for isolated TA.

\section{Case Report}

The propositae were born to a 41 -year-old, gravida 2, para 1 , blood type $\mathrm{A}+$ white female following a pregnancy during which there were no significant illnesses or exposures; there was no evidence of maternal diabetes mellitus. The family history was negative for congenital heart disease and for consanguinity. Elevated maternal serum alpha-fetoprotein prompted fetal ultrasonography at 14 weeks, which demonstrated a dichorionic, diamniotic twin pregnancy. Amniocentesis at 16 weeks showed each twin to have a $46, \mathrm{XX}$ karyotype. Sonograms obtained at 16 and 25 weeks were normal. The pregnancy proceeded without incident until the 31 st week, at which time ultrasonography showed both twins to be hydropic. Infectious and immunologic evaluations failed to reveal the etiology of the hydrops, and routine four-chamber ultrasonographic views of the fetal hearts showed no apparent defects.

Due to premature rupture of membranes, clinical evidence of chorioamnionitis, and signs of fetal distress, the mother was delivered via primary cesarean section at 33 
weeks. Twin "A" had Apgar scores of $4^{1} 6^{5}$. Her birth weight was $3140 \mathrm{~g}(>+2$ SD), her birth length was $48.5 \mathrm{~cm}(>+2 \mathrm{SD})$, and her birth OFC was $34 \mathrm{~cm}$ (+2 SD). Twin " $B$ " had Apgar scores of $6^{1} 7^{5}$; her birth weight was $2890 \mathrm{~g}(>+2 \mathrm{SD})$, her birth length was $46 \mathrm{~cm}(+1 \mathrm{SD})$, and her birth OFC was $32.5 \mathrm{~cm}$ (slightly <+2 SD). Physical examination showed nondysmorphic but markedly hydropic twin females, each with a holosystolic murmur and signs of congestive heart failure. There were no clinical features of the DiGeorge sequence. Twin " $B$ " had normal palmar creases; twin " $A$ " had a unilateral transitional crease. Both infants had A + blood types. Echocardiography (Fig. 1) revealed type I TA in each twin. Twin " $A$ " had moderately severe truncal valve insufficiency, and twin " $B$ " had severe truncal valve stenosis. DNA analysis (Lifecodes Corporation, Valnalla, New York) indicated that the twins were not monozygotic (Table 1).

Twin "A" underwent successful cardiac repair, consisting of ventricular septal defect closure and insertion of a homograft valve, and is alive at 11 months of age. She has hearing loss, possibly related to antibiotic therapy during early infancy, and delayed development. Twin " $B$ " died at 2 days of age, while undergoing cardiac catheterization and an attempt at balloon dilatation of the truncal valve. An autopsy demonstrated no additional malformations; the thymus and parathyroid glands were normal. The mother of the infants was found to have invasive, poorly differentiated squamous cell carcinoma of the cervix 7 weeks after the twins' birth.

\section{Discussion}

The suggested risk of recurrence of isolated TA is about $1 \%$ (Nora \& Nora 1988), and occurrence of TA in siblings has been reported infrequently. Goodyear (1961) described a brother and sister, each of whom had TA. Brunson et al. (1978) reported a family in which three out of four siblings were born with TA; their father had a history of patent ductus arteriosus and insulindependent diabetes mellitus, and a maternal great-uncle had an unspecified congenital heart defect. Although no member of the two families reported by Miller \& Smith (1979) had TA, several members had congenital heart disease owing to a defect in conotruncal septation, an embryologically related family of congenital heart defects to which TA belongs; they suggested that, in some cases, conotruncal septation defects may be transmitted in a monogenic, rather than multifactorial, fashion. Shapiro et al. (1981) described two brothers with single left ventricle and TA.

The concordance rate for congenital heart disease in twins is low, probably less than 10\% (Anderson 1977), and twins concordant for TA appear to have been reported only three times before. Giustra \& Tosti (1939) reported "identical" twin males, each of whom had cor biloculare with TA. Raghavan et al. (1983) reported monozygotic twins with multiple congenital anomalies (including sirenomelia and elements of VATER association in one, and phocomelia and other limb anomalies in the other) which included TA. Only the "homologous", monochorionic/diamniotic male twins de-

Flg. 1. Echocardiograms. A. Twin "A". Parasternal long axis view of the left ventricle, demonstrating the subaortic ventricular septal defect and the origin of the pulmonary artery from the common truncus arteriosus. B. Twin " $B$ ". Parasternal long axis view of the left ventricle, demonstrating the subaortic ventricular septal defect, the common truncus arteriosus, and the thickened truncal valve leaflets (arrows). LV = left ventricle; $R V=$ right ventricle; IVS = interventricular septum; TA = common truncus arteriosus; PA = pulmonary artery. 

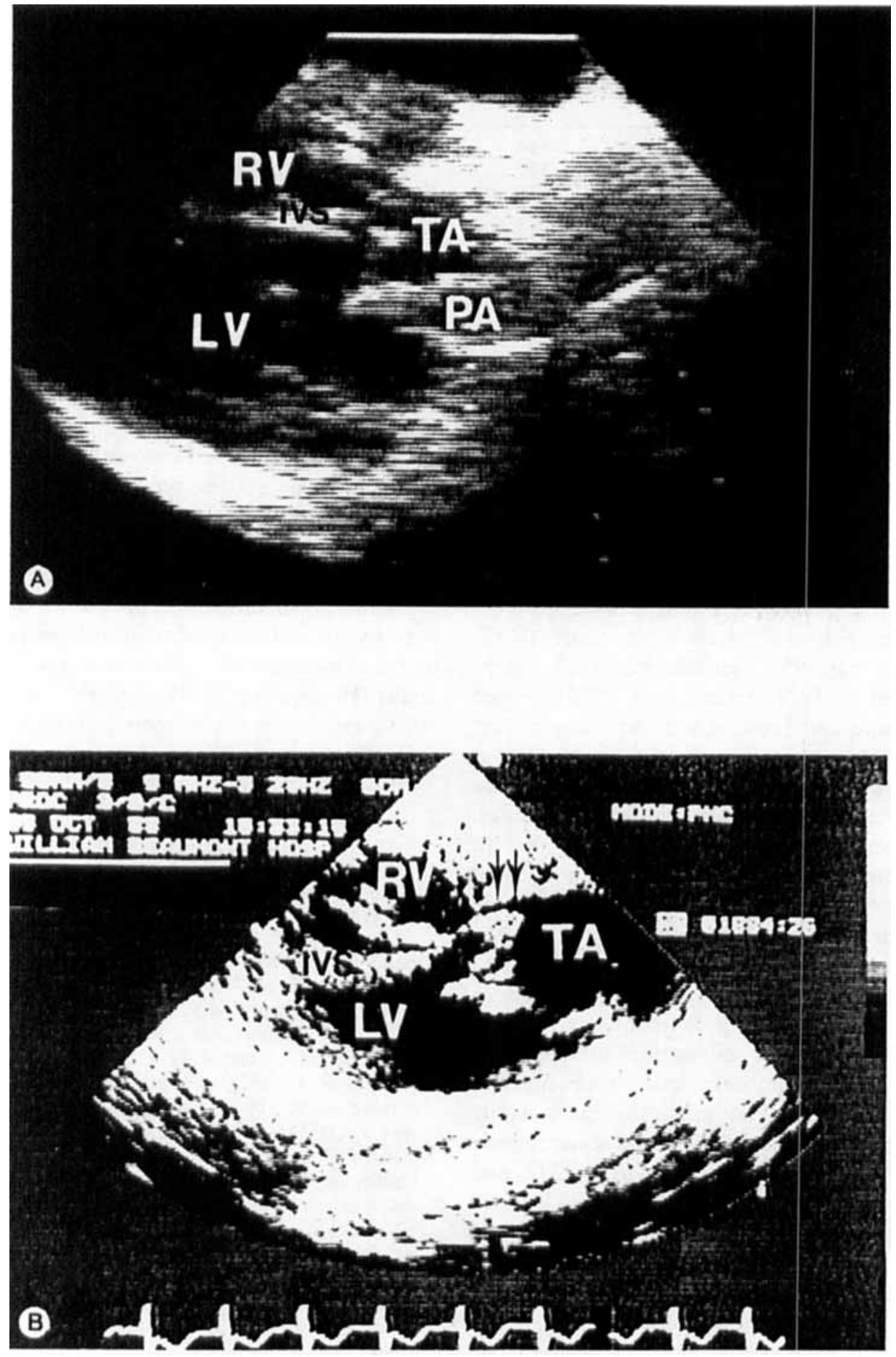
Table 1

Summary of DNA analysis (Lifecodes Corporation, Valhalla. New York)

\begin{tabular}{lcc}
\hline Locus/Enzyme & Twin "A" & Twin "B"* \\
\hline D17S79/Pst I & 3.84 & 3.84 \\
& 3.59 & 3.35 \\
D2S44/Pst I & 12.65 & 12.17 \\
& 12.17 & 9.66 \\
D14S1/Pst I & 4.13 & 9.10 \\
& 3.91 & 4.13 \\
\hline
\end{tabular}

- Allele tragment measurements, expresesed in kilo. base pairs.

scribed by Benešová \& Šikl (1954) appear to have had isolated TA without other anomalies. Review of several studies of congenital heart disease in twins (Uchida \& Rowe 1957, Ross 1959, Campbell 1961, Nora et al. 1967, Jörgensen 1970, Anderson 1976. Anderson 1977, Seides et al. 1979, Berg et al. 1989) and of several large studies of congenital heart disease in infancy (Richards et al. 1955, Menashe et al. 1967, Mitchell et al. 1971, Kenna et al. 1975) showed no additional instances of twins concordant for TA.

Most cases of congenital heart disease are believed to be due to multifactorial causes. A small proportion of cases are due to monogenic causes; in these cases, congenital heart disease is usually part of a syndrome (Nora \& Fraser 1989, pp. 321-328). In the present case, TA occurred as an isolated anomaly in each twin, and the occurrence of TA in these twins is compatible with either multifactorial or monogenic (autosomal recessive) inheritance. Although a number of agents have been implicated as possibly being both teratogenic and carcinogenic (e.g., $c f$. Nora \& Fraser 1989, p. 272, and Heggie et al. 1986), there is no evidence in this case that the occurrence of TA in the propositae and the occurrence of cervical carcinoma in their mother was other than an unfortunate coincidence.

We have presented what we believe to be the second report of twins concordant for isolated TA, and the first report of dizygotic twins concordant for this anomaly. Congenital heart disease was initially manifest as prenatally detected hydrops fetalis. The sudden, simultaneous onset of hydrops, and the normalcy of the fetal hearts on routine ultrasonographic examination, caused congenital heart disease to appear to be an unlikely etiology, and the cardiac origin of the hydrops was not recognized until postnatal echocardiography was conducted. TA may be diagnosed prenatally through the use of fetal echocardiography (Allan et al. 1985); furthermore, $\mathrm{TA}^{\text {}}$ has been detected in utero because of an abnormal four-chamber view of the heart on routine fetal ultrasonography (DeVore 1985). However, routine fourchamber views of the fetal hearts failed to demonstrate the presence of congenital heart disease in this case. This underscores the need to include fetal echocardiography in the evaluation of non-immune hydrops fetalis (Holzgreve et al. 1985, Carlton et al. 1989), even when the screening ultrasound evaluation is normal.

\section{References}

Allan, L. D., D. C. Crawford, R. H. Anderson \& $M$. Tynan (1985). Spectrum of congenital heart disease detected echocardiographically in prenatal life. Br. Heart J. 54, 523-526.

Anderson, R. C. (1976). Fetal and infant death, twinning and cardiac malformations in families of 2,000 children with and 500 without cardiac defects. Am. J. Cardiol. 38, 218-224.

Anderson, R. C. (1977). Congenital cardiac malformations in 109 sets of twins and triplets. Am. J. Cardiol. 39, 1045-1050.

Benešová, D. \& H. Sikl (1954). A rare concordant malformation in monochoriate twins: persistent common arterial trunk. J. Pathol. Bacteriol. 67, 367-370.

Berg, K. A., J. A. Astemborski, J. A. Boughman \& C. Ferencz (1989). Congenital cardiovascular malformations in twins and triplets from a population-based study. Am. J. Dis. Child. 143. 1461-1463. 
Brunson, S. C., D. B. Nudel, N. Gootman \& B. Aftalion (1978). Truncus arteriosus in a family. Am. Heart J. 96, 419-420.

Campbell, M. (1961). Twins and congenital heart disease. Acta Genet. Med. Gemellol. 10, 443-456.

Carlton, D. P., B. C. McGillivray \& M. D. Schreiber (1989). Nonimmune hydrops fetalis: a multidisciplinary approach. Clin. Perinatol. 16, 839-851.

DeVore, G. R. (1985). The prenatal diagnosis of congenital heart disease - a practical approach for the fetal ultrasonographer. $J$. Clin. Ultrasound 13, 229-245.

Giustra, F. X. \& V. G. Tosti (1939). True cor biloculare in identical twins. Am. Heart J. 17. 249-250.

Goodyear, J. E. (1961). Persistent truncus arteriosus in two siblings. Br. Heart J. 23, 194-196.

Heggie, A. D., W. B. Wentz, J. W. Reagan \& D. D. Anthony (1986). Roles of cytomegalovirus and Chlamydia trachomatis in the induction of cervical neoplasia in the mouse. Cancer Res. 46, 5211-5214.

Holzgreve, W., B. Holzgreve \& C. J. R. Curry (1985). Nonimmune hydrops fetalis: diagnosis and management. Semin. Perinatol. 9, 52-67.

Jörgensen, G. (1970). Twin studies in congenital heart disease. Acta Genet. Med. Gemellol. 19, $251-256$.

Kenna, A. P., R. W. Smithells \& D. W. Fielding (1975). Congenital heart disease in Liverpool: 1960-69. Q.J. Med. 44, 17-44.

Kidd, B. S. L. (1978). Persistent truncus arteriosus. In Heart Disease in Infancy and Childhood, 3rd Edit. J. D. Keith, R. D. Rowe \& P. Vlad (eds.) New York, McMillan Publishing Company, pp. 457-469.

Mair, D. D., W. D. Edwards, V. Fuster. J. B. Seward \& G. K. Danielson (1983). Truncus arteriosus. In Heart Disease in Infants, Children, and Adolescents, 3rd Edit. F. H. Adams \& G. C. Emmanouilides (eds.) Baltimore, Williams \& Wilkins, pp. 400-410.

Menashe, V. D., H. T. Osterud \& H. E. Griswold (1967). Mortality from congenital cardiovascu- lar disease in Oregon. Pediatrics 40, 334-344.

Miller, M. E. \& D. W. Smith (1979). Conotruncal malformation complex: examples of possible monogenic inheritance. Pediatrics 63, 890-893.

Mitchell, S. C., S. B. Korones \& H. W. Berendes (1971). Congenital heart disease in 56,109 births. Circulation 43, 323-332.

Nora, J. J., J. C. Gilliland, R. J. Sommerville \& D. G. McNamara (1967). Congenital heart disease in twins. $N$. Engl. J. Med. 277, 568-571,

Nora, J. J. \& A. H. Nora (1988). Update on counseling the family with a first-degree relative with a congenital heart defect. $A m$. J. Med. Genet. 29, 137-142.

Nora, J. J. \& F. C. Fraser (1989). Medical Genetics: Principles and Practice, 3rd Edit. Philadelphia, Lea \& Febiger.

Raghavan, K. R., L. M. Ambani, S. K. Ratnaparki, S. S. Dhareshwar, D. A. Khare \& J. N. Badbade (1983). Monozygotic twinning in sirenomelia. Indian Pediatr. 20, 308-309.

Richards, M. R., K. K. Merritt, M. H. Samuels \& A. G. Langmann (1955). Congenital malformations of the cardiovascular system in 6,053 infants. Pediatrics 15, 12-32.

Ross, L. J. (1959). Congenital cardiovascular anomalies in twins. Circulation 20, 327-342.

Seides, S. F., R. J. Shemin \& A. G. Morrow (1979). Congenital cardiac abnormalities in monozygotic twins: report and review of the literature. $B r$. Heart J. 42, 742-745.

Shapiro, S. R., R. N. Buckman, S. Kapur, R. Chandra, F. M. Galioto, L. W. Perry \& L. P. Scott, III (1981). Single ventricle with truncus arteriosus in siblings. Am. Heart J. 102 , 456-459.

Uchida, I. A. \& R. Rowe (1957). Discordant heart anomalies in twins. Am. J. Hum. Genet. $9,133-140$.

Address:

Michael J. Lang, $M D$

Division of Newborn Medicine

Department of Pediatrics

William Beaumont Hospital

3601 West Thirteen Mile Road

Royal Oak, Michigan

USA 48073 